\title{
Crop - Weed Modeling and Fitting Multiple Regression Equation in System of Rice Intensification
}

\author{
M.P. Kavitha ${ }^{1^{*}}$ and D. Janaki ${ }^{2}$ \\ ${ }^{1}$ Department of Vegetable Crops, ${ }^{2}$ Department of Fruits Crops, Horticultural College and \\ Research Institute, Tamil Nadu Agricultural University, Periyakulam- 625 604, India \\ *Corresponding author
}

\section{A B S T R A C T}

Field experiments were conducted at Agricultural Research Station, Vaigai Dam, Tamil Nadu Agricultural University during two consecutive kharif seasons of the years 2012 and

Keywords

Weed density, Crop dry matter production, Weed dry mater production,

Rate measurer

Article Info

Accepted:

20 August 2018

Available Online:

10 September 2018 2013 , to find out the cause effect relationship between weed density with crop dry matter production, weed dry matter production with crop dry matter production under System of Rice Intensification. The results revealed that, the rate measurer values of weed density on crop DMP were lower for pre emergence application of Pretilachlor @ $0.75 \mathrm{~kg} \mathrm{a}^{\mathrm{i}} \mathrm{ha}^{-1}+$ one mechanical weeding at 30 DAT during both years. This was attributed to lesser damage by weeds on growth due to effective suppression of weed density and weed DMP. The next lower rate measurer values were noticed with mechanical weeding three times @ 15, 30 and 45 DAT. A higher rate measurer value of weed density and weed DMP on crop DMP under other treatments showed that relatively higher aggressiveness of weed competition through the density and weed DMP. During both years grasses were more competitive than broad leaved weeds and sedges. Higher rate measurer values found for grasses showed the predominant occurrence of Echinochloa colonum seeds in the weed flora of previous crop.

\section{Introduction}

Rice is the most important food crop in the developing countries like India, accounting for nearly 29 per cent of the total calorie in take (FAO, 2001) and hence formed as life. Geometric growth of population and arithmetic increase in food grain production leave a vast gap in food supply. This gap is further widened due to urbanization and industrialization of fertile lands. In the global scenario, the present population of 6 billion is expected to reach by a figure of 9 billion by 2020. The global requirement of rice by 2025 AD would be 758 million tonnes which is 26 percent higher than the present level of production.

The farmers of Periyar Vaigai Command area of Tamil Nadu are reluctant to use too young seedlings (14 days) as it seems weak, lanky, tiny and require proper care in planting them 
at very shallow depth. As wider spacing (25 $\mathrm{cm}$ X $25 \mathrm{~cm}$ ), there are more weeds with SRI than the conventional cultivation (Jiaguo Zheng et al., 2004). The farmers are reluctant to use mechanical weeding at 30 days old crop in main field with false concept that it may damage the root and shoot system of the crop. Moreover, the farmers' reflection in the mechanical rotary weeder was not satisfactory due to its single man laborious operations which pain the individual; instead preference goes to group weeding. In order to cope up the need of weeding at this stage to control early emerging weeds can be made only through pre emergence application of herbicides. In System of Rice Intensification, mechanical weeding is done mainly for root pruning and soil aeration which may help in root proliferation. Since mechanical weeding is limited to some extent, humic acid is introduced to induce root and shoot activities to substitute the root pruning effect through mechanical weeding.

\section{Materials and Methods}

A field experiment was carried out at Agricultural Research Station, Vaigai Dam during consecutive kharif seasons of the years 20112 and 2013. The experimental soil was sandy clay loam with $\mathrm{pH}$ of 7.5 , which was medium in organic carbon $(0.53 \%)$, low in available nitrogen $(246.4 \mathrm{~kg} / \mathrm{ha})$, medium in phosphorus $(19.4 \mathrm{~kg} / \mathrm{ha})$ and medium in potassium $(250.0 \mathrm{~kg} / \mathrm{ha})$. The experiment was laid out in split plot design with three replications. The main plot consists of age of seedlings and weed management practices. Three age of seedling viz., $14\left(\mathrm{~A}_{1}\right), 18\left(\mathrm{~A}_{2}\right), 22$ $\left(\mathrm{A}_{3}\right)$ days old seedlings were evaluated with Four levels of weed management practices viz., Mechanical weeding 3 times at 15, 30, 45 DAT $\left(\mathrm{W}_{1}\right)$, Pre emergence application of Pretilachlor @ $0.75 \mathrm{~kg}$ a.i./ha plus one mechanical weeding at 30 DAT $\left(\mathrm{W}_{2}\right)$, Preemergence application of Pretilachlor @ 0.75 $\mathrm{kg}$ a.i. /ha + Post emergence application of 2-4 D sodium salt @ $1 \mathrm{~kg}$ a.i./ha $\left(\mathrm{W}_{3}\right)$ and Unweeded check $\left(\mathrm{W}_{4}\right)$. Three levels of humic acid application viz., Seedling dip $(0.3 \%$ humic acid), $\left(\mathrm{T}_{1}\right)$, Foliar spray $(0.1 \%$ humic acid) twice at 30 and $45 \operatorname{DAT}\left(\mathrm{T}_{2}\right)$ and Seedling dip ( $0.3 \%$ humic acid $)+$ Foliar spray (0.1\% humic acid) twice at 30 and 45 DAT $\left(\mathrm{T}_{3}\right)$ were assigned to sub plot. Short duration rice variety ADT 45 was grown during kharif (June-September) season of the years 2012 and 2013.

Fourteen, eighteen and twenty two days old seedlings derived from modified dapog mat nursery were used for transplanting in main plots. Hand operated mechanical weeder (rotary weeder) developed by Department of Agricultural Engineering, Tamil Nadu Agricultural University, Coimbatore, Tamil Nadu was used for mechanical weeding. Mechanical weeding was done as per treatment schedule. Application of herbicides viz.,Pre emergence Pretilachlor @ 0.75 kg/ha on third day after transplanting and the Post emergence 2,4 D Na salt @ $1 \mathrm{~kg} /$ ha on 25 DAT were made. The roots of rice seedlings were dipped in 0.3 percent humic acid solution for 1 hour and then transplanted. Nitrogen was applied as urea based on LCC schedule.

The LCC value was recorded as per the standard procedure (IRRI, 1996) at weekly intervals starting from 14 DAT to flowering. Whenever LCC values were found to be below the fixed critical level (No. 4), nitrogen @ 35 per hectare was applied. The entire dose of phosphorus (38 kg per ha) as single Super Phosphate (16 per cent $\mathrm{P}_{2} \mathrm{O}_{5}$ ) was applied as basal before transplanting. Recommended dose of potassium ( $38 \mathrm{~kg}$ per ha) in the form of Muriate of Potash (60 per cent $\mathrm{K}_{2} \mathrm{O}$ ) was applied in four splits viz., 25 per cent each at active tillering, panicle initiation, booting and flowering stages after the weeding was over. Zinc sulphate@25 kg per ha was applied as 
basal to crop during both the seasons. The data on weed population and weed dry matter were taken for crop weed modeling.

\section{Crop - weed modeling}

In order to find out the cause effect relationship between weed density with crop dry matter production, weed dry matter production with crop dry matter production, the following mathematical models were tried (Suyambulingam and Kailasam, 1988).

$Y=a+b x ; Y=a e^{b x} ; Y=a x^{n}$

Of the models tried for each, the best model was chosen for description. The choice of the best model was based on the highest $\mathrm{R}^{2}$ value. The estimate shows that the exponential model $\mathrm{Y}=\mathrm{a} \mathrm{e}^{\mathrm{bx}}$ is the best in almost all the cases indicating exponential damage to the drop due to weed competition.

Rate measurer is defined as the rate of change of dependent variable with respect to the change in the independent variable or it is first derivative of the function. If the relationship of the form $\mathrm{Y}=\mathrm{a} \mathrm{e}^{\mathrm{bx}}$, the rate measurer is $\mathrm{dy} / \mathrm{dx}=\mathrm{Y} \mathrm{b}$. The rate measurer values are used to compare and find out the best weed control method. Lower value of the rate measurer indicates the superiority over the other treatments.

Linear multiple regression equation was used to find out the cause and effects of the experiments whereas the quadratic paraboloid was used to fix the critical level of the different species which will cause the maximum damage to the crop.

The forms of equations are

$Y=b 0+b_{1} X_{1}+b_{2} X_{2}+\ldots \ldots \ldots \ldots$ and

$\mathrm{Y}=\mathrm{b} 0+\mathrm{b}_{1} \mathrm{X}_{1}+\mathrm{b}_{2} \mathrm{X}_{2}+\ldots \ldots \mathrm{C}_{1} \mathrm{X}_{1}{ }^{2}-\mathrm{C}_{2} \mathrm{X}_{2}{ }^{2}$

\section{Results and Discussion}

\section{Weed flora}

The weed flora of the experimental field was composite in nature, consisting of grasses, sedges and broad leaved weeds. Among them grasses were dominant weeds particularly with Echinochloa colonum in both the years. Under the sedge weed Cyperus rotundus was dominant and in broad leaved weeds Marsilea quadrifoliata as well as Sphenoclea zeylanica were the dominant weed species (Table 1).

Several workers (Gogoi et al., 2000; Jeevathayalan, 2002; Subramanian et al., 2005) reported that more grass weeds dominance in association with rice than broad leaved weeds.

During both the years of study, the relative density of grasses was higher than sedge and broad leaved weeds. This might be due to the fact that more number of seeds of Echinochloa colonum was present in the soil due to its predominant occurrence. This is in accordance with the findings of Singh et al., (2004).

\section{Crop -weed modeling}

In both models, rate measurer values were worked out to assess the effect of weed density and weed dry matter on crop dry matter production. A lower rate measurer value for any treatments indicates lesser damage by weeds on growth due to effective suppression of weed density and DMP. Accordingly the rate measurer values at 60 DAT showed that pre emergence application of Pretilachlor @ $0.75 \mathrm{~kg}$ a.i /ha + one mechanical weeding at 30 DAT $\left(\mathrm{W}_{2}\right)$ effectively controlled the weeds during both years of study (Table 2 and 3). This was attributed to lesser damage by weeds on growth due to effective suppression of weed density and weed DMP. The next lower rate 
measurer values were noticed with mechanical weeding three times at 15,30 and 45 DAT $\left(\mathrm{W}_{1}\right)$. The higher rate measurer values of weed density and weed DMP on crop DMP under other treatments showed the relatively higher aggressiveness of weed competition through density and weed DMP. A higher rate measurer values of weed density, weed DMP on rice DMP under Unweeded check $\left(\mathrm{W}_{4}\right)$ showed that the aggressiveness of weed competition through its density and DMP.

Rate measurer values worked out to compare the competitiveness of grasses, sedges and broad leaved weeds under unweeded check are as follows.

\section{Crop-weed modeling}

\begin{tabular}{|l|c|c|c|}
\hline & Grass & Sedge & Broad leaved weed \\
\hline Kharif 2012 & -108.85 & -118.42 & -112.59 \\
\hline Kharif 2013 & -95.21 & -191.16 & -107.46 \\
\hline
\end{tabular}

Table.1 Weed spectrum of the experimental field

\begin{tabular}{|l|l|l|l|}
\hline \multicolumn{1}{|c|}{ Botanical name } & \multicolumn{1}{|c|}{ Common name } & \multicolumn{1}{|c|}{ Family } & Life span \\
\hline A. Grasses & & & \\
\hline Echinochloa colonum & Jungle rice & Poaceae & Annual \\
\hline Cynodon dactylon & Bermuda grass & Poaceae & Perennial \\
\hline Panicum repens & Torpedo grass & Poaceae & Perennial \\
\hline B. Sedges & Purple nut sedge & Cyperaceae & Perennial \\
\hline Cyperus rotundus & Umbrella plant & Cyperaceae & Annual \\
\hline Cyperus difformis & Hoorah grass & Cyperaceae & Annual \\
\hline Fimbristylis miliaceae & & & \\
\hline C. Broad leaved weeds & Water fern & Marsileaceae & Annual \\
\hline Marsilea quadrifoliata & & Sphenocleaceae & Annual \\
\hline Sphenoclea zeylanica & Karisalanganni (T) & Compositae & Annual \\
\hline Eclipta alba & Neergrampoo (T) & Onagraceae & Annual \\
\hline Ludwigia parviflora & & &
\end{tabular}


Table.2 Effect of total weed density and total weed DMP on rice DMP at 60 DAT during 2012

\begin{tabular}{|c|c|c|c|c|c|c|c|c|}
\hline \multirow[t]{2}{*}{ Treatment } & \multicolumn{4}{|c|}{ Total weed density on crop DMIP } & \multicolumn{4}{|c|}{ Weed DMP on crop DMP } \\
\hline & $\mathbf{a}$ & b & $\mathbf{r}^{2}$ & $\begin{array}{c}\text { dy/dx (Rate } \\
\text { measurer) }\end{array}$ & $\mathbf{a}$ & b & $\mathbf{r}^{2}$ & $\begin{array}{l}\text { dy/dx (Rate } \\
\text { measurer) }\end{array}$ \\
\hline $\mathbf{W}_{1}$ & 1470 & -0.08663 & 0.8169 & -57.41 & 1375 & -0.5490 & 0.9107 & -371.70 \\
\hline $\mathbf{W}_{2}$ & 1355 & -0.0823 & 0.9602 & -60.16 & 1677 & -0.7243 & 0.9390 & -520.53 \\
\hline $\mathbf{W}_{3}$ & 1665 & -0.0665 & 0.9533 & -39.89 & 1861 & -0.5059 & 0.9425 & -310.14 \\
\hline $\mathbf{W}_{4}$ & 1662 & -0.0835 & 0.9543 & -38.75 & 1735 & -0.5590 & 0.9777 & -244.43 \\
\hline
\end{tabular}

Table.3 Effect of total weed density and total weed DMP on rice DMP at 60 DAT during 2013

\begin{tabular}{|c|c|c|c|c|c|c|c|c|}
\hline \multirow[t]{2}{*}{ Treatment } & \multicolumn{4}{|c|}{ Total weed density on crop DMP } & \multicolumn{4}{|c|}{ Weed DMIP on crop DMIP } \\
\hline & $\mathbf{a}$ & b & $\mathbf{r}^{2}$ & $\begin{array}{c}\text { dy/dx (Rate } \\
\text { measurer) }\end{array}$ & $\mathbf{a}$ & b & $\mathbf{r}^{2}$ & $\begin{array}{c}\text { dy/dx (Rate } \\
\text { measurer) }\end{array}$ \\
\hline $\mathrm{W}_{1}$ & 1642 & -0.0809 & 0.8841 & -63.43 & 1508 & -0.5612 & 0.9690 & -452.65 \\
\hline $\mathbf{W}_{2}$ & 2155 & -0.1259 & 0.7917 & -108.85 & 2674 & -1.1700 & 0.8993 & -976.35 \\
\hline $\mathbf{W}_{3}$ & 2460 & -0.0801 & 0.8789 & -58.69 & 2489 & -0.5904 & 0.8782 & -447.20 \\
\hline $\mathbf{W}_{4}$ & 1512 & -0.0612 & 0.7718 & -36.59 & 1542 & -0.4311 & 0.8642 & -247.65 \\
\hline
\end{tabular}

Table.4 Effect of species wise weed density on rice DMP at 60 DAT during 2012

\begin{tabular}{|c|c|c|c|c|c|c|c|c|c|c|c|c|}
\hline \multirow[t]{2}{*}{ Treatment } & \multicolumn{4}{|c|}{ Grass weed density on crop DMP } & \multicolumn{4}{|c|}{ Sedge weed density on crop DMP } & \multicolumn{4}{|c|}{$\begin{array}{l}\text { Broad leaved weed density on crop } \\
\text { DMP }\end{array}$} \\
\hline & $\mathbf{a}$ & B & $\mathbf{r}^{2}$ & $\begin{array}{c}\text { dy/dx } \\
\text { (Rate } \\
\text { measurer) }\end{array}$ & $\mathbf{a}$ & b & $\mathbf{r}^{2}$ & $\begin{array}{c}\mathrm{dy} / \mathrm{dx} \\
\text { (Rate } \\
\text { measurer) }\end{array}$ & $\mathbf{a}$ & b & $\mathbf{r}^{2}$ & $\begin{array}{c}\text { dy/dx } \\
\text { (Rate } \\
\text { measurer) }\end{array}$ \\
\hline $\mathbf{W}_{1}$ & 1347 & -0.1793 & 0.8761 & -125.06 & 1753 & -0.2738 & 0.8998 & -175.95 & 928 & -0.1883 & 0.9018 & -124.09 \\
\hline $\mathbf{W}_{2}$ & 1418 & -0.2077 & 0.9351 & -152.02 & 1128 & -0.3333 & 0.9068 & -241.23 & 1425 & -0.2222 & 0.9892 & -163.28 \\
\hline $\mathbf{W}_{3}$ & 1735 & -0.1985 & 0.9698 & -123.54 & 1730 & -0.1861 & 0.9641 & -114.83 & 1196 & -0.1581 & 0.8937 & -94.98 \\
\hline $\mathrm{W}_{4}$ & 1617 & -0.2314 & 0.9401 & -108.85 & 1354 & -0.2501 & 0.9064 & -118.42 & 1900 & -0.2520 & 0.9328 & -112.59 \\
\hline
\end{tabular}


Table.5 Effect of species wise total weed density on rice DMP at 60 DAT during 2013

\begin{tabular}{|c|c|c|c|c|c|c|c|c|c|c|c|c|}
\hline \multirow[t]{2}{*}{ Treatment } & \multicolumn{4}{|c|}{ Grass weed density on crop DMP } & \multicolumn{4}{|c|}{ Sedge weed density on crop DMP } & \multicolumn{4}{|c|}{ Broad leaved weed density on crop DMP } \\
\hline & $\mathbf{a}$ & b & $\mathbf{r}^{2}$ & $\begin{array}{c}\text { dy/dx (Rate } \\
\text { measurer) }\end{array}$ & $\mathbf{a}$ & b & $\mathbf{r}^{2}$ & $\begin{array}{c}\text { dy/dx (Rate } \\
\text { measurer) }\end{array}$ & $\mathbf{a}$ & b & $\mathbf{r}^{2}$ & $\begin{array}{l}\text { dy/dx (Rate } \\
\text { measurer) }\end{array}$ \\
\hline $\mathrm{W}_{1}$ & 1537 & -0.1714 & 0.7812 & -142.41 & 2310 & -0.3096 & 0.6870 & -235.73 & 1060 & -0.1602 & 0.8358 & -125.03 \\
\hline $\mathrm{W}_{2}$ & 2241 & -0.3079 & 0.7416 & -265.25 & 1554 & -0.4855 & 0.6889 & -411.30 & 2303 & -0.3319 & 0.8226 & -291.98 \\
\hline $\mathbf{W}_{3}$ & 2501 & -0.2426 & 0.8789 & -184.34 & 2451 & -0.2141 & 0.8823 & -162.98 & 1692 & -0.1968 & 0.8847 & -143.60 \\
\hline$W_{4}$ & 1498 & -0.1623 & 0.7133 & -95.21 & 1380 & -0.2009 & 0.7378 & -191.16 & 1540 & -0.1771 & 0.8092 & -107.46 \\
\hline
\end{tabular}

Table.6 Multiple regression equation with crop DMP and growth attributes

\begin{tabular}{|c|c|c|c|c|}
\hline \multirow{2}{*}{$\begin{array}{l}\text { Treat- } \\
\text { ment } \\
\text { tested }\end{array}$} & \multicolumn{2}{|l|}{2012} & \multicolumn{2}{|l|}{2013} \\
\hline & Equations & $\begin{array}{c}\mathbf{R}^{2} \\
\text { value }\end{array}$ & Equations & $\begin{array}{c}\mathbf{R}^{2} \\
\text { value }\end{array}$ \\
\hline$\overline{\mathbf{A}_{1}}$ & $\begin{array}{l}Y=-74640.9+1801.73 x_{1}-5973.67 x_{2}+2942.89 x_{3}-657.71 \\
x_{4}\end{array}$ & $0.898 * *$ & $Y=-26158.2+1762.7 x_{1}-5206.89 x_{2}-129.4 x_{3}-155.81 x_{4}$ & $0.889 * *$ \\
\hline$\overline{\mathbf{A}_{2}}$ & $\begin{array}{l}Y=-21550.7-1854.69 x_{1}+120.01 x_{2}+1230.15 x_{3}+792.77 \\
x_{4}\end{array}$ & $0.866 * *$ & $Y=-711.17+446.46 x_{1}+1754.46 x_{2}+47.36 x_{3}-81.15 x^{4}$ & $0.851 * *$ \\
\hline$\overline{\mathbf{A}_{3}}$ & $Y=-2935.8+157.70 x_{1}+2435.63 x_{2}+146.03 x_{3}-1.49 x_{4}$ & $0.933 * *$ & $Y=-4812.88+224.9 x_{1}+1592.17 x_{2}-9.02 x_{3}+69.59 x_{4}$ & $0.945^{* *}$ \\
\hline$\overline{W_{1}}$ & $Y=-47668+1378.48 x_{1}+5797.16 x_{2}-422.87 x_{3}+20.96 x_{4}$ & $0.950 * *$ & $Y=-39758.4+439.31 x_{1}+3849.3 x_{2}+121.0 x_{3}+224.62 x_{4}$ & $0.945 *$ \\
\hline $\mathbf{W}_{2}$ & $Y=-118572+1727.25 x_{1}-2483.92 x_{2}-620.31 x_{3}+863.73 x_{4}$ & $0.883 *$ & $Y=-26842.5+948.57 x_{1}+2166.55 x_{2}-667.3 x_{3}+182.67 x_{4}$ & $0.919 *$ \\
\hline $\mathbf{W}_{3}$ & $Y=-4447.71-1243.83 x_{1}+4453.82 x_{2}+95.25 x_{3}+586.29 x_{4}$ & $0.863 *$ & $Y=-9655.56-700.45 x_{1}+5207.6 x_{2}-160.28 x_{3}+486.21 x_{4}$ & $0.866 *$ \\
\hline $\mathbf{W}_{4}$ & $Y=-92931.1-185.51 x_{1}-6168.32 x_{2}+422.99 x_{3}+1281.90 x_{4}$ & $0.975^{* *}$ & $\begin{array}{l}Y=-84104.8+42.21 x_{1}-5276.72 x_{2}+304.83 x_{3}+1096.03 \\
x_{4}\end{array}$ & $0.982 *$ \\
\hline $\mathbf{T}_{1}$ & $Y=-6624.86+461.84 x_{1}+248.94 x_{2}+431.15 x_{3}-131.99 x_{4}$ & $0.920 * *$ & $Y=-6306.22+423.88 x_{1}-532.48 x_{2}-358.25 x_{3}-77.54 x_{4}$ & $0.983 * * * \%$ \\
\hline $\mathbf{T}_{2}$ & $Y=-6884.66+53.34 x_{1}+1522.59 x_{2}+409.45 x_{3}+35.40 x_{4}$ & $0.948 * *$ & $Y=-10469+409.41 x_{1}-340.44 x_{2}+288.7 x_{3}+2.82 x_{4}$ & $0.952 * *$ \\
\hline $\mathbf{T}_{\mathbf{3}}$ & $Y=-38315-297.92 x_{1}-2060.84 x_{2}+467.91 x_{3}+595.29 x_{4}$ & $0.946 * *$ & $Y=-27336.1+246.35 x_{1}-1283.18 x_{2}-183.14 x_{3}+314.83 x_{4}$ & $0.904 * *$ \\
\hline
\end{tabular}


Table.7 Multiple regression equation with yield and yield attributes

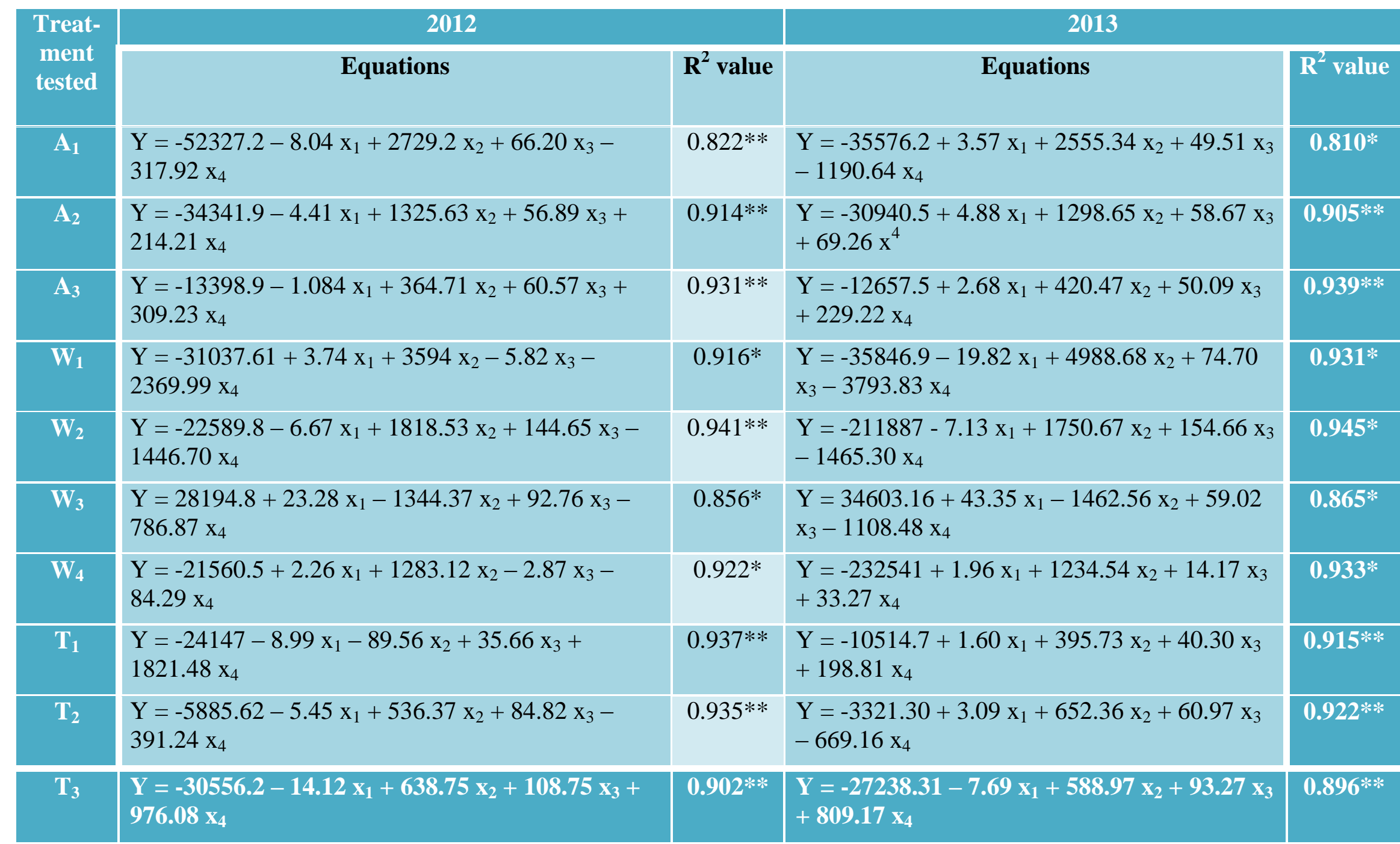

* Significant at 5\% level; ** Significant at $1 \%$ level

$\mathrm{Y}=$ yield $\mathrm{x}_{1}=$ productive tillers $\mathrm{m}^{-2} ; \mathrm{x}_{2}=$ panicle length; $\mathrm{x}_{3}=$ filled grains panicle ${ }^{-1} ; \mathrm{x}_{4}=1000$ grain weight 
During both years, grasses were more competitive than broad leaved weeds and sedges. However, in case of mechanical weeding three times at 15, 30 and 45 DAT $\left(\mathrm{W}_{1}\right)$, broad leaved weeds were more competitive as they recorded higher rate measurer value during both years of study (Table 4 and 5). Higher rate measurer values found for grasses showed the predominant occurrence of Echinochloa colonum seeds in the weed flora of previous crop. This is in line with the findings of Balasubramanian (1996).

\section{Multiple regression}

Important growth parameters (LAI, SPAD, root volume and plant height) and yield attributes (number of productive tillers $\mathrm{m}^{-2}$, panicle length, filled grains per panicle and test grain weight) as independent variables were selected to fit the multiple regression function for the dependent variables DMP and grain yield respectively. The selected growth attributing characters contributed to the crop DMP with $r^{2}$ values in the range of 0.851 to 0.945 for age of seedlings, 0.863 to 0.982 for weed management practices and 0.904 to 0.983 for humic acid application (Table 6). Similarly the selected yield attributing characters contributed to the grain yield with $\mathrm{r}^{2}$ values in the range of 0.810 to 0.939 for age of seedlings, 0.856 to 0.945 for weed management practices ad 0.896 to 0.937 for humic acid application (Table 7). The correlation index $\mathrm{r}^{2}$ indicated that the multiple regression equation was the good indicator for the DMP and grain yield for different age of seedlings, weed management practices and humic acid application.

The results of the present study explained the potential of agronomic practices viz., age of seedlings, weed management practices and humic acid application in rice under SRI techniques in improving grain yield of rice that could be exploited and extended to the farmer's field to sustain the self-sufficiency in food grain production.

\section{References}

Balasubramanian, R. 1996. Weed management in rice based crop sequence through herbicides in nursery, pre plant tillage and herbicide rotation. $\mathrm{Ph} . \mathrm{D}$ Thesis submitted to and approved by Tamil Nadu Agricultural University, Coimbatore.

FAO. 2001. Medium term projections for the world rice economy major issues at stake. Food and Agriculture Organization. Int. Rice. Comm. Newsletter, 50: 1-6.

Gogoi, A.K., D.J. Rajkhowa and R. Kandal. 2000. Effect of varieties and weed control practices on rice (Oryza sativa) productivity and weed growth. Indian J. Agron., 45(3): 580-585.

IRRI. 1996. Use of Leaf Colour Chart (LCC) for $\mathrm{N}$ management in Rice. Int. Rice Res. Inst., P.O Box. 933, Manila 1099, Philipines.

Jeevathayalan, V. 2002. Evaluation of the herbicide "Almix - post application" in transplanted rice crop. M.Sc. (Ag) Thesis submitted to and approved by Tamil Nadu Agricultural University, Coimbatore, Tamil Nadu.

Jiaguo Zheng., Xianjun Lu, Xinlu Jiang and Younglu Tang. 2004. The system of rice intensification (SRI) for super high yields of rice in Sichuan basin. In: Proc. of the $4^{\text {th }}$ International Crop Science Conference, Brisbane, Australia, 26 Sep-Oct, 2004.

Singh, U.P., Y. Singh and Vinod Kumar. 2004. Effect of weed management and cultivars in boro rice (Oryza sativa) and weeds. Indian J. Weed Sci., 36(1\&2): 57-59.

Subramanian, E., G. James Martin and S. Ramasamy. 2005. Effect of weed and 
nitrogen management on weed control and productivity of wet seeded rice. Indian J. Weed Sci., 37(172): 61-64.
Suyambulingam, C. and S. Kailasam. 1988. Mathematics for plant sciences. Sakthi publications, Coimbatore, Tamil Nadu.

\section{How to cite this article:}

Kavitha, M.P. and Janaki, D. 2018. Crop - Weed Modeling and Fitting Multiple Regression Equation in System of Rice Intensification. Int.J.Curr.Microbiol.App.Sci. 7(09): 3005-3013. doi: https://doi.org/10.20546/ijcmas.2018.709.374 